\title{
Pollution Impact and Alternative Treatment for Produced Water
}

\author{
Yusran Hedar ${ }^{1, *}$ and Budiyono ${ }^{2}$ \\ ${ }^{1}$ Master Program of Environmental Science, School of Postgraduate Studies, Diponegoro University, Semarang - Indonesia \\ ${ }^{2}$ Department of Chemical Engineering, Faculty of Engineering, Diponegoro University, Semarang - Indonesia
}

\begin{abstract}
Oil and gas exploration and production are two of the activities that potentially cause pollution and environmental damage. The largest waste generated from this activity is produced water. Produced water contains hazardous pollutants of both organic and inorganic materials, so that the produced water of oil and gas production cannot be discharged directly to the environment. Uncontrolled discharge can lead to the environmental damage, killing the life of water and plants. The produced water needs to be handled and fulfill the quality standards before being discharged to the environment. Several studies to reduce the contaminants in the produced water were conducted by researchers. Among them were gravity based separation - flotation, separation technique based on filtration, and biological process treatment. Therefore, some of these methods can be used as an alternative waste handling of produced water.
\end{abstract}

\section{Introduction}

The significance of oil and natural gas in modern civilization is well known. Nevertheless, oil and gas exploration and production activities produce solid, liquid, and gas waste with $80 \%$ liquid waste composition, even it reaches $95 \%$ in the old oil fields. Produced water is the largest liquid waste generated by the activity [1]. Oilfield wastewater or produced water contains various organic and inorganic components. Discharging produced water can pollute surface and underground water and soil [2].

The produced water can be from the saline water and formation water. There are three sources of saline water: Flow from above or below the hydrocarbon zone, Flow from within the hydrocarbon zone, Flow from injected fluids and additives resulting from production activities. The last category is called "connote water" or "formation water" and becomes produced water when saline water mixed with hydrocarbons comes to the surface [3]. Global produced water production is estimated at around 250 million barrels per day compared with around 80 million barrels per day of oil. As a result, water to oil ratio is around $3: 1$ that is to say water cut is $70 \%$. Oil fields are responsible for more than $60 \%$ of produced water generated worldwide $[2,4]$. The large number of the produced water can be used for various purposes, such as underground injection to increase oil production, irrigation, livestock or wildlife watering and habitats, and various industrial uses (e.g., dust control, vehicle washing, power plant makeup water, and fire control) $[2,3]$.

Continuation of large produced water discharges is expected because the water cut (the relative amount of water to oil) increases with the age of the production wells $[2,14]$. Thus, the question of biological effects of produced water discharges is a matter of continued relevance. Usually, produced water is treated to remove dispersed oil by either flotation or gravity in separation tank batteries, and then discharged to the environment. Alternatively, it may be injected into a nearby nonproducing well [15].

Before being disposed to the environment, the produced water need treatment to meet the quality requirement of waste water set by the Government. Production quality standard in Indonesia is regulated by the Regulation of the Minister of Environment Number 19 Year of 2010 regarding the quality standard of waste water for businesses and/or activities of oil and gas and geothermal. The regulation determines that the maximum permissible concentration for COD is 200-300 $\mathrm{mg} / \mathrm{L}$, oil and fat are $25-50 \mathrm{mg} / \mathrm{L}$, dissolved sulfide is $0.5 \mathrm{mg} / \mathrm{L}$, ammonia is $5 \mathrm{mg} / \mathrm{L}$ and phenol is $2 \mathrm{mg} / \mathrm{L}$ [5]. The permitted oil and grease (O\&G) limits for treated produced water discharge offshore in Australia are $30 \mathrm{mg} / \mathrm{L}$ (milligram per liter) daily average and 50 $\mathrm{mg} / \mathrm{L}$ instantaneous [6]. Based on United States Environmental Protection Agency (USEPA) regulations, the daily maximum limit for $\mathrm{O} \& \mathrm{G}$ is $42 \mathrm{mg} / \mathrm{L}$ and the monthly average limit is $29 \mathrm{mg} / \mathrm{L}$ [7]. As regards the significant matter of environmental concern, many countries have implemented more stringent regulatory standards for discharging produced water. The monthly average limits of $O \& G$ discharge and chemical oxygen demand (COD) prescribed by the Peoples Republic of China are 10 and $100 \mathrm{mg} / \mathrm{L}$, respectively [8]. Based on the Convention for the Protection of the Marine Environment of the North-East Atlantic (OSPAR Convention), the annual average limit for discharge of

Corresponding author: yusranhedar@gmail.com 
dispersed oil for produced water into the sea is $40 \mathrm{mg} / \mathrm{L}[2]$.

The utilization of the produced water and the disposal of untreated produced water containing many hazardous materials can interfere with the environmental sustainability. The characteristics of the produced water must be known to provide an appropriate way to reduce the content of hazardous substances in the water prior to the disposal. Appropriate management and handling are needed, so the produced water can be disposed to the environment safely and can be utilized properly in order not to interfere with environmental sustainability. In this review will be discusses about the introduction of produced water, the impact of produced water discharge on the environment, and technology that has been used in handling of produced water.

\section{Produced Water}

Produced water (also called formation water, brine or saltwater) is water from underground formations that is brought to the surface during oil or gas production. The water is discharged in an oily form after its separation from the real oil. During oil and gas exploration other forms of wastewater are produced, these include injected water, little quantity of water that is condensed and traces of some chemicals used among which produced water is the highest generated by-product [24]. The physical and chemical properties of produced water vary considerably depending on the geographic location of the field, the geo-logic formation, and the type of hydrocarbon product being produced [24,25]. Dispersed oil, aromatic hydrocarbons and alkylphenols (AP), heavy metals, and naturally occurring radioactive material (NORM) are of particular environmental concern $[25,26]$. Because the water has been in contact with hydrocarbon-bearing formations, it contains some of the chemical characteristics of the formations and the hydrocarbons. It may include water from the reservoir, water previously injected into the formation, and any chemicals added during the production processes. The composition and characteristics of naturally occurring chemical substances in produced water are closely associated to the geological characteristics of each reservoir [25]. Produced water is mostly discharged to the immediate aquatic environment; the organic and inorganic compounds in produced water have higher toxicity to the environment than crude oil.

\subsection{Characteristic of produced water}

Produced waters characteristics depend on the nature of the producing/storage formation from which they are withdrawn, the operational conditions, and chemicals used in process facilities. The composition of produced water from different sources can vary by order of magnitude. However, produced water composition is qualitatively similar to oil and/or gas production $[2,9,10]$.

Produced water is a mixture of organic and inorganic materials. Some factors such as geological location of the field, its geological formation, lifetime of its reservoirs, and type of hydrocarbon product being produced affect the physical and chemical properties of produced water [3]. The major compounds of produced water include:

a. Dissolved and dispersed oil compounds

b. Dissolved formation minerals,

c. Production chemical compounds,

d. Production solids (including formation solids, corrosion and scale products, bacteria, waxes, and asphaltenes),

e. Dissolved gases $[2,11,12]$

Although produced water varies significantly among wells and fields, several groups of constituents are present in most types of produced water. The major constituents of concern in produced water are salt content (expressed as salinity, total dissolved solids, or electrical conductivity), oil and grease, and various natural inorganic and organic compounds [16]. Sulphate reducing bacteria may also be present in produced water [24].

\subsection{Produced water from oilfield}

The produced water from the oil processing may contain groundwater or seawater injected to maintain the reservoir pressure and also the content of solid particles and bacteria. Most produced water contains more saline water than sea water. Besides, the produced water contains chemical compounds used in the drilling process and the production process as well as the process of separation of water and oil. The chemical compounds for processing are usually the complex mixture of many molecular compounds. The mixture may contain:

a. Corrosion inhibitor and oxygen remover to reduce the risk of corrosion of equipment

b. Crust inhibitor that limits deposits of the mineral crust

c. Biocide compounds to reduce bacterial fouling

d. Emulsion destroyer and emulsion purifier to destroy water emulsion in oil and vice versa

e. Coagulants, flocculants, and purifiers to remove solids

f. Solvent to reduce paraffin deposit

In the produced water, these chemical compounds can affect the coefficients of partition, toxicity, bioavailability, and biodegradability. In line eith the development of the oil fields, these compounds are needed in large quantities to ensure flow in the underwater piping system [16]. Table 1 summarizes a range of produced water characteristics in different oilfields in the world. The data show ranges of pollutants and constituents that are present in produced water. 
Table 1. Summary of oilfield-produced water parameters in world [2, 17].

\begin{tabular}{|c|c|c|c|}
\hline Parameter & Values & Heavy metal & Values (mg/L) \\
\hline Dens ity $\left(\mathrm{kg} / \mathrm{m}^{3}\right)$ & $1014-1140$ & Calcium & $13-25800$ \\
\hline Surface Tension (dynes/cm) & $43-78$ & Sodium & 132-97000 \\
\hline TOC (mg/L) & $0-1500$ & Potassium & $24-4300$ \\
\hline $\mathrm{COD}(\mathrm{mg} / \mathrm{L})$ & 1220 & Magnesium & $8-6000$ \\
\hline $\mathrm{TSS}(\mathrm{mg} / \mathrm{L})$ & $1.2-1000$ & Iron & $<0.1-100$ \\
\hline $\mathrm{pH}$ & $4.3-10$ & Aluminum & $310-410$ \\
\hline Total oil (IR; mg/L) & $2-565$ & Boron & $5-95$ \\
\hline Volatile (BTX; mg/L) & $0.39-35$ & Barium & $1.3-650$ \\
\hline Base/neutrals (mg/L) & $<140$ & Cadmium $^{\mathrm{a}}$ & $<0.005-0.2$ \\
\hline (Total non-volatile oil and grease by GLC/MS) base & 275 & Chromium & $0.02-1.1$ \\
\hline Chloride $(\mathrm{mg} / \mathrm{L})$ & $80-200,000$ & Copper & $<0.002-1.5$ \\
\hline Bicarbonate (mg/L) & $77-3990$ & Lithium & $3-50$ \\
\hline Sulfate $(\mathrm{mg} / \mathrm{L})$ & $<2-1650$ & Manganese & $<0.004-175$ \\
\hline Ammonia nitrogen $(\mathrm{mg} / \mathrm{L})$ & $10-300$ & Lead $^{\mathrm{a}}$ & $0.002-8.8$ \\
\hline Sulfite $(\mathrm{mg} / \mathrm{L})$ & 10 & Strontium & $0.02-1000$ \\
\hline Total polar $(\mathrm{mg} / \mathrm{L})$ & $9.7-600$ & Titanium & $<0.01-0.7$ \\
\hline Higher acids (mg/L) & $<1-63$ & $\mathrm{Zinc}^{\mathrm{a}}$ & $0.01-35$ \\
\hline Phenols $(\mathrm{mg} / \mathrm{L})$ & $0.009-23$ & Arsenic $^{\mathrm{a}}$ & $<0.005-0.3$ \\
\hline \multirow[t]{3}{*}{ VFA's (volatile fatty acids) (mg/L) } & $2-4900$ & Mercury & $<0.001-0.002$ \\
\hline & & Silver ${ }^{a, b}$ & $<0.001-0.15$ \\
\hline & & Beryllium & $<0.001-0.004$ \\
\hline
\end{tabular}

a Analyzed by atomic absorption.

b Value should be regarded as a minimum due to poor solubilities.

\subsection{Produced water from gas fields}

In gas fields, water injection is not utilized; therefore, the produced waters are mixture of formation water and condensed water. Their chloride content varies from almost those of fresh water to salty formation water with chloride concentration about 14 times that of seawater. Its acidity is greater than that of produced water from oilfields $[2,18]$.
The volume of produced water from gas field is less than in oilfields. A wide range of gas treatment chemicals is used in gas fields including methanol, ethylene glycol, and triethylene glycol. About one-third of these chemicals are discharged in produced water $[2,6]$. Volatile components concentrations in produced water from gas fields are higher than those in produced water from oilfields [2,19]. Table 2 shows concentrations of constituents in produced water from gas

fields.

Table 2. Constituents $(\mathrm{mg} / \mathrm{L})$ in natural gas produced waters ( $\mathrm{pH}$ is presented in standard units) $[2,20]$.

\begin{tabular}{|c|c|c|c|c|c|}
\hline Parameter & Minimum & Maximum & Parameter & Minimum value & Maximum value \\
\hline $\mathrm{pH}^{\mathrm{a}}$ & 4.4 & 7.0 & Iron $^{\mathrm{a}}$ & ND & 1100 \\
\hline $\mathrm{pH}^{\mathrm{b}}$ & 3.1 & 6.47 & Iron $^{\mathrm{b}}$ & 39 & 680 \\
\hline Conductivity ${ }^{\mathrm{a}}$ (umhos/cm) & 4200 & 180,000 & Lead $^{\mathrm{b}}$ & $<0.2$ & 10.2 \\
\hline Conductivity ${ }^{\mathrm{b}}$ (umhos/cm) & 136,000 & 586,000 & Lithium ${ }^{\mathrm{b}}$ & 18.6 & 235 \\
\hline Alkalinity & 0 & 285 & Magnesium ${ }^{\mathrm{a}}$ & 0.9 & 4300 \\
\hline $\operatorname{TDS}^{\mathrm{a}}$ & 2600 & 310,000 & Magnesium ${ }^{b}$ & 1300 & 3900 \\
\hline TDS $^{b}$ & 139,000 & 360,000 & Manganese $^{\mathrm{a}}$ & 0.045 & 6.5 \\
\hline $\mathrm{TSS}^{\mathrm{a}}$ & 14 & 800 & Manganese $^{b}$ & 3.59 & 63 \\
\hline TSS $^{\mathrm{b}}$ & 8 & 5484 & Nickel $^{\mathrm{a}}$ & ND & 0.02 \\
\hline $\mathrm{BOD}^{\mathrm{a}}$ & 75 & 2870 & Nickel $^{\mathrm{b}}$ & $<0.08$ & 9.2 \\
\hline $\mathrm{COD}^{\mathrm{a}}$ & 2600 & 120,000 & Potassium $^{\text {b }}$ & 149 & 3870 \\
\hline Aluminum ${ }^{\mathrm{a}}$ & ND & 0.4 & Silver ${ }^{b}$ & 0.047 & 7 \\
\hline Aluminum ${ }^{b}$ & $<0.50$ & 83 & Sodium ${ }^{\mathrm{a}}$ & 520 & 45,000 \\
\hline Arsenic $^{\mathrm{a}}$ & 0.004 & 1 & Sodium ${ }^{b}$ & 37,500 & 120,000 \\
\hline Arsenic ${ }^{b}$ & $<0.005$ & 151 & Strontium ${ }^{\mathrm{a}}$ & - & 6200 \\
\hline Barium ${ }^{\mathrm{a}}$ & ND & 26 & Sulfate ${ }^{\mathrm{a}}$ & $<0.1$ & 47 \\
\hline Barium $^{\mathrm{b}}$ & 9.65 & 1740 & Sulfate ${ }^{b}$ & ND & 19 \\
\hline Boron $^{\mathrm{a}}$ & ND & 56 & $\operatorname{Tin}^{\mathrm{a}}$ & ND & 1.1 \\
\hline Bromide $^{\mathrm{b}}$ & 150 & 1149 & Zinc $^{a}$ & ND & 0.022 \\
\hline Cadmium $^{\mathrm{a}}$ & ND & 0.015 & Zinc $^{\mathrm{b}}$ & $<0.02$ & 5 \\
\hline Cadmium $^{\mathrm{b}}$ & $<0.02$ & 1.21 & $\mathrm{TOC}^{\mathrm{a}}$ & 67 & 38.000 \\
\hline Calcium $^{\mathrm{a}}$ & ND & 25,000 & Surfactants ${ }^{\mathrm{b}}$ & 0.08 & 1200 \\
\hline Calcium $^{\mathrm{b}}$ & 9400 & 51,300 & Benzene $^{\mathrm{a}}$ & 1.8 & 6.9 \\
\hline Chloride $^{\mathrm{a}}$ & 1400 & 190,000 & Benzene $^{c}$ & $<0.010$ & 10.3 \\
\hline Chloride $^{\mathrm{b}}$ & 81,500 & 167,448 & Toluene $^{\mathrm{a}}$ & 0.857 & 3.37 \\
\hline Chromium $^{\mathrm{a}}$ & ND & 0.03 & Toluene $^{\mathrm{c}}$ & $<0.010$ & 18 \\
\hline Copper $^{\mathrm{a}}$ & ND & 0.02 & Oil/grease ${ }^{\mathrm{a}}$ & 6 & 60 \\
\hline Copper $^{b}$ & $<0.02$ & 5 & Oil/grease ${ }^{b}$ & 2.3 & 38.8 \\
\hline
\end{tabular}

a [21].

b [22].

c [23]. 


\section{Environmental Effects of Produced Water}

The effect of produced water in a certain environment depends on the physical, chemical and biological composition of such environment. Findings indicate that in spite of all the level of toxicity of produced water effluent, there is paucity of information on their real impact on the exposed ecology [24,27]. Produced water from oil and gas industries often is permitted to be discharged to the environment [2,28]. In offshore drilling, produced water are mostly discharged to the immediate aquatic environment. The organic and inorganic compounds in produced water have higher toxicity compared to that of crude oil. The discharge of these toxic constituents and contaminants to the aquatic environment pose threat to aquatic life and agricultural resources by altering the natural state of the aquatic environment [24,29]. Water's toxicity and organic loading can generally characterize the impact of discharging produced water into the sea $[2,11]$.

Produced water is a mixture of inorganik and organic compounds. Salinity is a general attribute of produced water. Salinity or salt concentration, describe as TDS, can vary in produced waters from 1.000$400.000 \mathrm{mg} / \mathrm{L}$ [33]. Environmental effect of produced water salts can occur in all regions where oil and gas have been produced [2,30]. Sodium is a major dissolved constituent in most produced waters and it causes substantial degradation of soils through altering of clays and soil textures and subsequent erosion. High sodium levels compete with calcium, magnesium, and potasium for uptake by plant roots, therefore, excess sodium can prompt deficiencies of other cations. Elevated levels of sodium also can cause poor soil structure and inhibit water infiltration in soil [33]. Produced water salts seem to have the most wide-ranging effects on soils, water quality, and ecosystems [30]. It is as a major contributor of toxicity [6]. Salinity is higher in produce water than some sea water which could result to aquatic destruction in fresh water [24,31]. Inorganic ions (e.g., sodium, potasium, calcium, and chloride) are not concern in produced water discharges to the ocean [36] but are of environmental concern when the treated water dischargesd to land or surface fresh or brackish water [26].

The produced water content that has the potential to cause damage to the environment is the organic material. Organic matter in produce water exist in two form: dispersed oil and non-hydrocarbon organic material. Dispersed oil is small, discrete droplets suspended in the water. Nonhydrocarbon organic material is dossolved in the water [33,34]. Dispersed oil and droplets do not precipitate at the bottom of sea but rise to the surface of water. Volatile and/or toxic compounds evaporate. These materials increase the biochemical oxygen demand (BOD) of the affected water $[2,32]$. Worldwide research has proven that produced water effluents are as-sociated with high level of biological oxygen demand (BOD) and chemical oxygen demand (COD) which are generated from compounds of fatty acids [24]. Nonpolar organics from different sources of produced water are consistently toxic $[2,36]$. Produced water toxicity can be expressed as acute or chronic toxicity. Acute toxicity can be measured by the LC50 test, but long-term effects or chronic toxicity are more difficult to quantify $[2,11]$.

Some produced waters contain chemicals that are highly toxic to sensitive marine species, even at low concentrations. When discharge is to shallow, enclosed coastal waters, or when discharge is of a lowdensity produced water in an area with low water turbulence and current speeds, concentrations of produced water chemicals may remain high for long enough to cause ecological harm [6]. The chemicals of greatest environmental concern in produced water, because their concentrations may be high enough to cause bioaccumulation and toxicity include aromatic hydrocarbons, some alkylphenols, and a few metals. Highly alkylated phenols (octyl- and nonyl-phenols) are well-known endocrine disruptors, but rarely are detected in produced water at high enough concentrations to cause harm to water column animals following initial dilution [26,37].

Most metals and naturally-occurring radionuclides are present in produced water in chemically reactive dissolved forms at concentrations similar to or only slightly higher than concentrations in seawater and, therefore, are unlikely to cause adverse effects in the receiving water environment [6]. Heavy metal toxicity is less than nonpolar organics in produced water [36]. If produced water is discharged to shallow estuarine and marine waters, some metals and higher molecular weight aromatic and saturated hydrocarbons may accumulate in sediments near the produced water discharge, possibly harming bottom living biological communities [26].

Schifter et al. [16] studied the effect of produced water effluents in Sonda de Campeche located in Gulf Mexico, This study is based on direct field sampling of effluent released into the ocean in the years 2003 and 2013. The result showed that Nicel, $\mathrm{Cr}, \mathrm{Pb}$, and As has increases values in 2013. The sum of average metal concentration increased from 2,72 to $11,04 \mu \mathrm{g} / \mathrm{L}$ in the decade. Otherwise, it was found that TPHs increased by two in the water at diffuser area during the decade. Fish tissues at the discharge zone and reference site are contaminated with PAHs, dominated by 2- and 3-rings; 4-ring accounted for less than 1\% oh total PAHs in 2003, but increased to $7 \%$ in 2013 .

Some production treatment chemicals are toxic and, if they are discharged at high concentration in produced water, could cause localized harm [26]. Water-soluble production chemicals do not have toxicity effects in the aqueous phase compared to oil soluble production chemicals at the same concentration. However, some production chemicals can increase partitioning of oil compounds into the aqueous phase at high concentrations [29]. Treatment chemicals can precipitate and accumulate in marine sediments [39].

Produced water from gas production tend to have higher higher content of low molecular weight aromatic 
hydrocarbon such as benzene, toluene, ethylbenzene, and xylene (BTEX) than produced water from oil production. Studies indicate that the produced water discharge from gas/condensate platform are about 10 times more toxic than produced water discharged from oil platform [18,33].

\section{Produced Water Treatment}

Produced water is considered an oilfield waste. Whether waste or commodity, produced water management has a cost. For managing produced water, a three-tiered pollution prevention hierarchy is followed:

- Employing technologies to minimize produced water production,

- Reuse and recycling,

- If neither of these tiers is practical, disposal is the final option $[2,40]$.

Some of the options available to oil and gas operators for produced water management proposed by Arthur et al. [41] are as follows:

- Injection: injection of produced water into the same formation from which the oil is produced or handle to another formation.

- Discharge: treatment of produced water to meet onshore or offshore discharge regulations.

- Reuse in oil and gas operation: treat the produced water to meet the quality required to use it for usual oil and gas fields operations.

- Consume in beneficial use: produced water treatment to meet to quality required for beneficial uses such as irrigation [42], rangeland restoration, cattle and animal consumption, and drinking water.

Because produced water may contain many different types of contaminants and the concentration of contaminants varies significantly, numerous types of treatment technologies have been proposed to treat produced water. Treatment of produced water is an effective option for produced water handling. Treatment of produced water has the potential to be a harmless and valuable product rather than a waste. The general objectives for operators for treating produced water are as follows[41]:

a) De-oiling: removing dispersed oil and grease,

b) Soluble organics removal,

c) Disinfection,

d) SS removal: removing of suspended particles and sand,

e) Dissolved gas removal: removing of light hydrocarbon gases, carbon dioxide, and hydrogen sulfide,

f) Desalination: removing dissolved salts,

g) Softening: removing excess water hardness,

h) Miscellaneous: removing NORM.

Most often, an effective produced water treatment system will consist of many different types of individual unit processes used in series to remove a wide suite of contaminants that may not be removed with a single process [33]. In general, some of the technologies used for treating the produced water are gravity based separation flotation, separation technique based on filtration, and biological process treatment.

\subsection{Gravity Separation}

Most commonly used water treating equipment depends on the forces of gravity to separate the oil droplets from the water continuous phase. The oil droplets, being lighter than the volume of water they displace, have a buoyant force exerted on them. This is resisted by a drag force caused by the vertical movement through the water [43]. Oil and grease removal methods depend on the end usage of treated water and composition of oil in the produced water [41]. Table 3 shows typical performance for oil removal treatment as expressed by oil particle size.

Table 3. Oil and grease removal technologies based on size of removable particles $[41,44]$.

\begin{tabular}{lc}
\hline \multicolumn{1}{c}{ Oil Removal Technology } & $\begin{array}{c}\text { Minimum size of particles removed } \\
\text { (mic rons) }\end{array}$ \\
\hline API gravity separator & 150 \\
Corrugated plate separator & 40 \\
Induced gas floatation (no flocculants) & 25 \\
Induced gas floatation (with flocculants) & $3-5$ \\
Hydroclone & $10-15$ \\
Mesh coalescer & 5 \\
Media filter & 5 \\
Centrifuge & 2 \\
Membrane filter & 0.01 \\
\hline
\end{tabular}




\subsubsection{Corrugated Plate Interceptors (CPI)}

The use of flow through parallel plates to help gravity separation in skim tanks was pioneered in the late 1950s as a method of modifying existing refinery horizontal, rectangular cross-section separators to treat oil droplets less than $150 \mu \mathrm{m}$ in diameter. Various configurations of plate coalescers have been devised. These are commonly called parallel plate interceptors (PPI), corrugated plate interceptors (CPI), or cross-flow separators. All of these depend on gravity

separation to allow the oil droplets to rise to a plate surface where coalescence and capture occur [43].

The first form of a plate coalescer was the PPI. This involved installing a series of plates parallel to the longitudinal axis of an API separator (a horizontal, rectangular cross-section skimmer). The plates form a "V" when viewed along the axis of flow so that the oil sheet migrates up the underside of the coalescing plate and to the sides. Sediments migrate toward the middle and down to the bottom of the separator, where they are removed [43].

The most common form of PPI used in production operations is the CPI. This is a refinement of the PPI in that it takes up less plan area for the same particle size removal, it makes sediment handling easier, and it has the added benefit of being cheaper than a PPI [43]. Corrugated plates are packed to enhance the performance of gravity separation tanks (Figure 1). The oil droplets coalesce and form larger oil droplets as the corrugated plates provide a longer path for the oil droplets to travel to the top of the tank. It is a simple operation that allows the compact design of the API separation tank; however, the efficient oil removal limits the oil droplet size of 40 microns and larger. Removal of smaller oil droplets is difficult with corrugated plate separator [41].

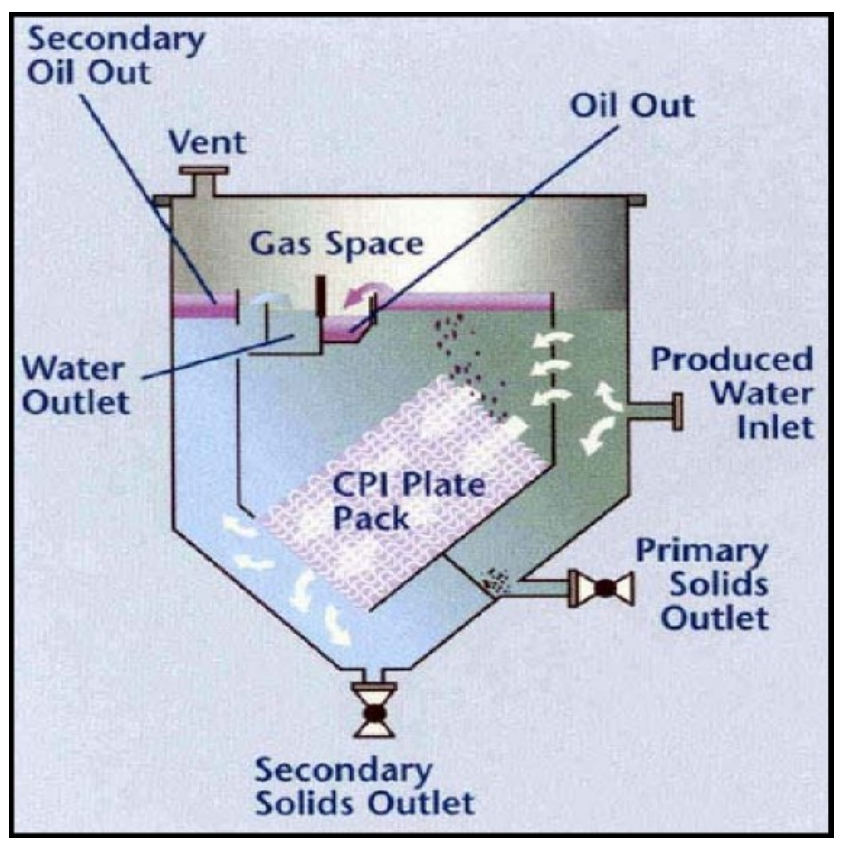

Fig. 1. Corrugated Plate (CPI) packing separates oil and solids from produced water [41,43].

Deng et al. [2,45] proposed crossflow oil-water separator for polymer flooding. The system consisted of different coalescence and separator sections. Sludge was removed from the bottom and oil and gas was separated from the top. Oil concentration in treated produced water fell to less than $100 \mathrm{ppm}$. Fig. 2 shows a schematic of the system. Van den Broek and Van der
Zande [2,46] compared oil removal efficiencies of different de-oiling systems. Their rankings with respect to performance of three physical separators were: centrifuges, hydrocyclones, and plate separators. Besides the low removal efficiency of these systems, dissolved and hazardous components could not be removed. 


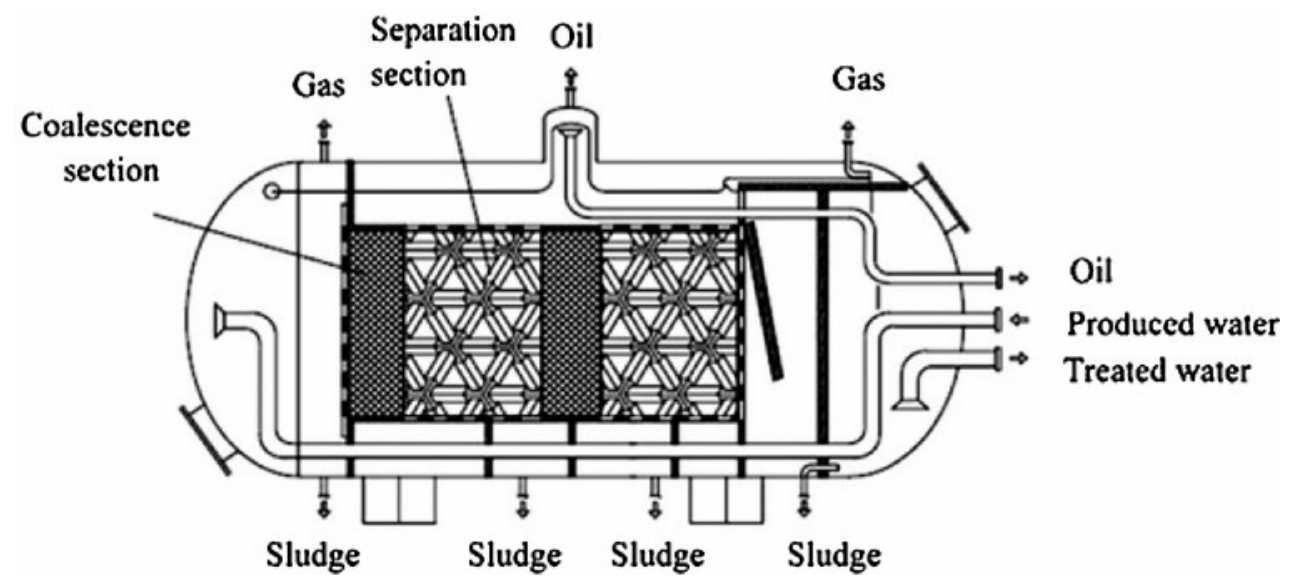

Fig. 2. Schematic illus tration of crossflow oil-water separator $[2,45]$

\subsubsection{Flotation}

Flotation is a process in which fine gas bubbles are used to separate small, suspended particles that are difficult to separate by settling or sedimentation. Gas is injected into the water to be treated, and particulates and oil droplets suspended in the water are attached to the air bubbles, and they both rise to the surface. As a result, foam develops on the surface, which is commonly removed by skimming. The dissolved gas can be air, nitrogen, or another type of inert gas. Dissolved air/gas flotation also can be used to remove volatile organics and oil and grease. Dissolved air flotation units have been widely used for treatment of produced water $[33,47,48]$.

Gas flotation technology is subdivided into dissolved gas flotation (DGF) and induced gas flotation (IGF). The two technologies differ by the method used to generate gas bubbles and the resultant bubble sizes. In DGF units, gas (usually air) is fed into the flotation chamber, which is filled with a fully saturated solution. Inside the chamber, the gas is released by applying a vacuum or by creating a rapid pressure drop. IGF technology uses mechanical shear or propellers to create bubbles that are introduced into the bottom of the flotation chamber, shows at figure 3. Coagulation can be used as a pretreatment to flotation [33,41]. Efficient performance is limited to oil droplet size of greater than 25 microns. To achieve higher efficiency if smaller droplets are present. Produced water treatment systems based on micro-bubble floatation system have been developed which use 5-50 micrometer bubbles through the reactor $[41,49]$. Smaller bubbles more effectively separate oil from the produced water which results in low skim volume [41]. Flotation works well in cold temperatures and can be used for waters with both high and low TOC concentrations. It is excellent for removing natural organic matter (NOM) and can be used to treat water containing TOC, oil and grease, and particulates $<7 \%$ solids [33]. In one reported study, flotation achieved an oil removal of 93\% [50].

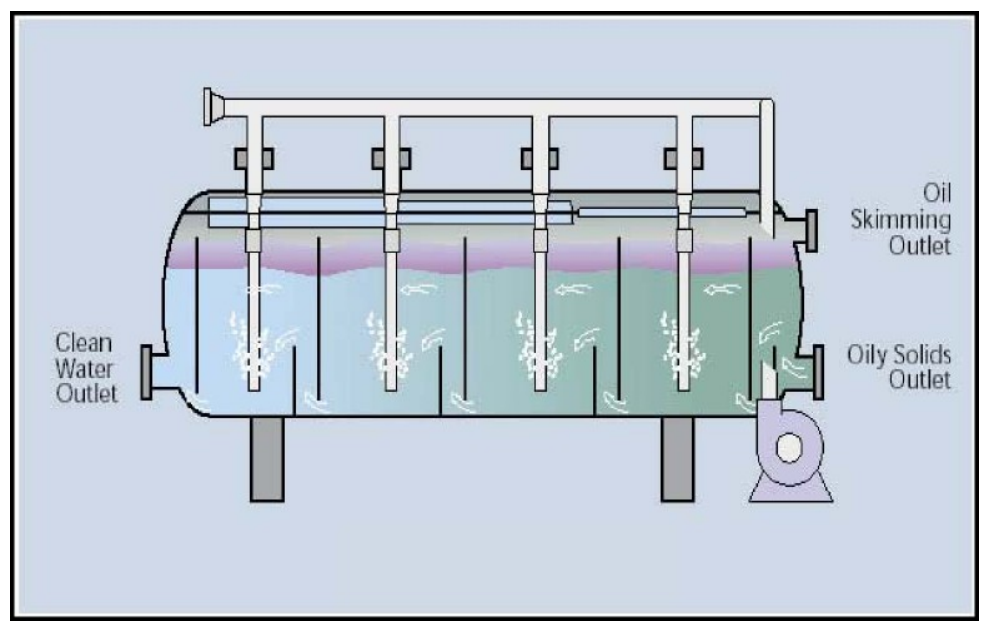

Fig. 3. Induced gas floatation cell [41]

\subsubsection{Hydrocyclones}

Hydrocyclones have been used extensively to treat produced water and are marketed by numerous companies for produced water treatment $[33,53]$. In offshore installations because of space constraints, compact systems with small and 
light characteristics are favorable. Seureau et al. [52] designed a three-phase cyclonic separator to remove solids and oil from offshore-produced water. The system combines the functional characteristics of both desanding and de-oiling hydrocyclones.

Hydrocyclones can be used to separate liquids and solids or liquids of different densities. Hydrocyclones can be used to remove particulates and oil from produced water. Depending on the model of hydrocyclone employed, they can remove particles in the range of 5-15 micrometers $(\mu \mathrm{m})$ $[33,51]$. Hydrocyclones will not remove soluble oil and grease components $[33,47]$.

Hydrocyclones generate spinning motion of the fluid that creates centrifugal force to push heavier water outward and lighter oil into the middle core of the cones. The water continues down and exits out the tapered end. The improved gravity effect provides a higher rate of separation [41]. Hydrocyclones can be used to treat water with high solids and organic chemical concentrations and can reduce oil and grease concentrations to $10 \mathrm{ppm}$. High product water recovery is possible with this technology [33].

\subsection{Adsorption}

Adsorption is a widely accepted technology for the removal of soluble hydrocarbons from the produced water. Adsorption columns are packed with porous solid material known as adsorbent. The hydrocarbons present in the produced water adhere onto the surface of adsorbent and are eventually retained within the porous structure. The effluent from the adsorption column contains little or no hydrocarbons. Highly porous adsorbents with higher surface area offer better performance [41].

Adsorption can be accomplished using a variety of materials, including zeolites, organoclays, activated alumina, and activated carbon. Chemicals are not required for normal operation of adsorptive processes. Chemicals may be used to regenerate media when all active sites are occupied. Periodically, the media is backwashed to remove large particulates trapped between the voids in the media. Typically, these processes can be gravity fed and do not require an energy supply, except during backwash [33].

Adsorbents are capable of removing iron, manganese, total organic carbon, BTEX compounds, heavy metals, and oil from produced water. Adsorption is generally utilized as a unit process in a treatment train rather than as a stand-alone process. The adsorbent can be easily overloaded with large concentrations of organics, so this process is best used as a polishing step rather than as a primary treatment process. Adsorption is capable of removing over $80 \%$ of heavy metals and can accomplish nearly $100 \%$ product water recovery[33].

Activated carbon can remove soluble BTEX but organoclay can remove insoluble free hydrocarbons that contribute to total petroleum hydrocarbons (TPH) and O\&G measurement [2]. Copolymer beads are prepared based on methylmethacrylate (MMA) and divinylbenzene (DVB) by suspension polymerization.
These copolymers can reduce oil content of produced water to around $85 \%[2,54]$. Zeolites are often used as ion-exchange resins. Use of hydrophobic zeolite pellets in a fixed bed to adsorb dissolved organic compounds in produced water is proposed $[2,11]$. Janks and Cadena [55] used "tailored" zeolites, to remove BTEX from saline produced water. They were made by adsorbing neutralized amines onto natural zeolites. The projected process removal efficiency was $70-85 \%$ [2].

Doyle et al. tested the combination of ET Ventures' ET \#1 (a modified polymer or bentonite or an organoclay) and granular activated carbon in packed bed adsorption column. The treatment system could remove hydrocarbons consistently and effectively. Results showed that the system reduced total petroleum hydrocarbon and $O \& G$ to non-detectable levels, and reduced soluble hydrocarbons: benzene, ethylbenzene, toluene, and xylene too to barely detectable levels. The main drawback of adsorption systems is the need for frequent regeneration of materials and the generation of waste $[2,56]$.

\subsection{Membrane Separation Technologies}

Membranes are thin films of synthetic organic or inorganic materials, which selectively separate a fluid from its components. Membrane separation processes such as Microfiltration (MF), Ultrafiltration (UF), Nano filtration (NF), and Reverse Osmosis (RO) can be used to separate different sized materials. MF is separation of suspended particles, UF is the separation of macromolecules, and RO is the separation of dissolved and ionic components [2]. NF membranes are generally designed to be selective for multivalent ions rather than for univalent ions. RO membranes are designed to reject all species other than water. They are unable to offer a significant barrier to dissolved gases and certain lowmolecular weight organic molecules [2]. Various applications of the pressure driven membrane technologies are listed in Table 4. Molecular Weight Cutoff (MWCO) is the ability of a membrane to reject the species of certain molecular weight measured as Daltons [41].

MF is a process of sieving particulates based on the pore size of the membrane. The pore size of MF is about $0,1 \mu \mathrm{m}$ or more, therefore its application in produced water treatment should be considered as a pretreatment in order to enhance the effectiveness of UF, NF or RO processes [59]. Abbasi et al [60] studied usage of mullite and mullite-alumina ceramic MF membranes for the treatment of produced water. Result obtained are the TOC rejection of $94 \%$ for the synthetic oily wastewater but only $84 \%$ of the TOC rejection for the real produced water using the same membrane.

Zhu et al. [61] reported the use of hydrophilic and oleophobic polyvinylidene fluoride (PVDF) hollow fiber MF membranes for the oil-water separation. The modified polymers were added as additives to the 
PVDF dope solution in order to make hydrophilic and oleophobic PVDF hollow fiber MF membranes. Three different types of oils namely 'H-oil' (Hexane in water), 'C-oil' (crude oil in water) and 'P-oil' (palm oil in water) were studied for the oil-water separation using the new hydrophilic and oleophobic PVDF hollow fiber membrane. Result of their experiment are The 'H-oil' removal efficiency of $>98 \%$ was achieved and the 'Coil' removal was impressive, $>99 \%$. However the 'P-oil' showed only about $70 \%$ separation efficiency due to the smaller size of oil droplet in the feed water [59].

Table 4. Applications of advanced membrane filtration technologies [41].

\begin{tabular}{|c|c|c|}
\hline Membrane Filtration & Separation Specifications & Applications/Removal \\
\hline Microfiltration (MF) & $\begin{array}{c}>100,000 \text { Daltons } \\
10-0.1 \mu \mathrm{m}\end{array}$ & bacteria, viruses, suspended solids etc \\
\hline Ultrafiltration (UF) & $\begin{array}{c}10,000 \text { to } 100,000 \text { Daltons } \\
0.05-5 \mathrm{e}^{-3} \mu \mathrm{m}\end{array}$ & $\begin{array}{l}\text { proteins, starch, viruses, colloid silica, } \\
\text { organics, dyes, fats, paint solids etc }\end{array}$ \\
\hline Nanofiltration (NF) & $\begin{array}{c}1,000 \text { to } 100,000 \text { Daltons } \\
5 \mathrm{e}^{-3}-5 \mathrm{e}^{-4} \mu \mathrm{m}\end{array}$ & $\begin{array}{l}\text { starch, sugar, pesticides, } \\
\text { herbicides, divalent ions, } \\
\text { organics, BOD, COD, detergents etc }\end{array}$ \\
\hline Reverse Osmosis (RO) & $\begin{array}{l}\text { salts and lower MWCO } \\
1 \mathrm{e}^{-4}-1 \mathrm{e}^{-5} \mu \mathrm{m}\end{array}$ & $\begin{array}{l}\text { metal ions, acids, sugars, aqueous salts, dyes, } \\
\text { natural resins, monovalent salts, BOD, } \\
\text { COD, ions etc }\end{array}$ \\
\hline
\end{tabular}

UF is one of the most effective methods for oily wastewater treatment, especially for produced water, in comparison with the traditional separation methods because of its high oil removal efficiency, there is no necessity for chemical additives, energy costs are low, and space requirements small $[2,57]$. In a study, Safitri et al. [58] studied Ultrafiltration process using membrane polyethersulfone (PES) from NADIR, Germany, with pore size of $10 \mathrm{kDa}$ to treat oilfield produced water. Result of their experiment showed that $90 \%$ of COD rejection, $99,5 \%$ of O\&G rejection, $83 \%$ of toluene rejection and $82 \%$ of xylene rejection.

Bilstad and Espedal compared MF and UF membranes in pilot trial to treat the North Sea oilfieldproduced water. Results showed that UF, but not MF, could meet effluent standards for total hydrocarbons, SS, and dissolved constituents. By UF membrane treatment with molecular weight cut-off (MWCO) was between 100,000 and 200,000 Da, total hydrocarbon concentration could be reduced to $2 \mathrm{mg} / \mathrm{L}$ from $50 \mathrm{mg} / \mathrm{L}$ ( $96 \%$ removal). Benzene, toluene, and xylene (BTX) were reduced by $54 \%$, and some heavy metals like $\mathrm{Cu}$, and $\mathrm{Zn}$ were removed to the extent of $95 \%$ [2].

Both NF and RO membranes are operated at relatively high pressure compared to MF and UF membranes. In RO membrane, the water permeation flux is directly proportional to the operating pressure whereas the salt permeation is independent of pressure. Therefore, membrane is more selective when operated in high pressure [62]. Both NF and RO membranes are effective in removing inorganic minerals. The major difference between NF and RO membrane is the selectivity. The RO membrane rejects all the ionic species including monovalent ions whereas the NF is more selective for the divalent ions and partially allows the monovalent ions like $\mathrm{Na}^{+}$and $\mathrm{Cl}-$. Most of the NF and nearly all of the modern RO membranes are made as thin film composite (TFC) membrane on an asymmetric UF membrane support. Since these membranes are highly selective at the high pressure operation, these membranes are easily prone to fouling and therefore require relatively clean feed water in terms of suspended solids, clay, organic foulants etc [59].

\subsection{Biological Treatment}

Aerobic and anaerobic microorganisms were used in studies of biological treatment of produced water. In aerobic treatment, researchers used activated sludge, trickling filters, sequencing batch reactors (SBRs), chemostate reactors, biological aerated filters (BAF), and lagoons [2].

Activated sludge is the usual method for treating wastewater. In a continuous-flow pilot plant, an oil skimmer was used to remove oil before treatment in an activated sludge system. Naturally occurring microbial growth was used in an aeration tank. The activated sludge treatment unit could maintain a total petroleum hydrocarbon (TPH) removal efficiency of $98-99 \%$ at a solids retention time (SRT) of 20 days [2]. Freire et al. [63] studied COD removal efficiency of acclimated sewage sludge in SBR with different percentages of produced water and sewage. In $45 \%$ and $35 \%$ (v/v) mixtures of wastewater, COD removal efficiencies varied from $30 \%$ to $50 \%$ [2].

$\mathrm{BAF}$ is a well established technology and has been used for produced water treatment for many years. BAF can remove oil, suspended solids, ammonia, and nitrogen, chemical oxygen demand, biological oxygen demand, iron, manganese, heavy metals, soluble organics, trace organics, and hydrogen sulfide. Iron and manganese removal in BAFs is mainly due to chemical oxidation rather than a biological process. BAF is most effective on waters with chloride levels below 6,600 $\mathrm{mg} / \mathrm{L}$, oil concentrations less than $60 \mathrm{mg} / \mathrm{L}$; COD less than 400 $\mathrm{mg} / \mathrm{L}$, and BOD less than $50 \mathrm{mg} / \mathrm{L}$ [33]. Approximate removal capabilities of BAFs technology are 60 to $90 \%$ nitrification; 50 to $70 \%$ total nitrogen; 70 to $80 \%$ oil; 
30 to $60 \%$ COD ; 85 to $95 \%$ BOD; 75 to $85 \%$ suspended solids [33].

Hidayat and Kardena [64] studied the removal of $\mathrm{COD}$ as an organic compound in produced water using indogenous bacteria originating from Total E \& P waste water treatment site. The results showed that indogenous bacteria can be used in organic compound removal with removal efficiencies of $88.21 \%$. However, nitrogen and phosphorus bind to indogenous bacteria in degrading organic compounds

In biological oxidation, harmless bacteria, algae, fungi, and protozoa convert dissolved organics and ammonia compounds into water and $\mathrm{CO} 2$, nitrates/nitrites, respectively, but have no effect on TDS [2]. The dominant mechanism of hydrocarbon removal by microorganisms in biological treatment is biodegradation and occluding particles by microorganisms similar to bio-flocculation. Activated sludge has the property of adsorbing and occluding not only soluble but also insoluble materials. Bacteria produce surface-active compounds such as surfactants (biosurfactants) and emulsifiers (bioemulsifiers) that enhance the local pseudo-solubility of hydrocarbons and thus improve mass transfer to biodegrading bacteria. Biodegradation of less complex oil components, e.g., normal alkanes is easier than of complex and large molecules. Less biodegradable oil molecules attached to microorganisms will remain in the aeration tank. These components are removed along with sludge in excess-sludge removal processes. The mixture of hydrocarbons and microorganisms are a source of hazardous material which has to be disposed [2].

\section{Conclusion}

The produced water is the largest liquid waste generated from oil and gas production activities. It contains hazardous materials such as, (1) organic matters which include dispersed, dissolved and emulsified oil, and grease, (2) inorganic matters which is commonly referenced as TDS, and (3) Heavy metals. The materials can contaminate the environment. The produced water produced prior to the disposal to the environment must already meet the required quality standards. Several handling technologies can be done to reduce and eliminate the contaminants in the produced water, namely gravity separation, floatation, adsorption, membrane separation and biological treatment. The combination use of several technologies is needed to achieve the optimal results. Therefore, the produced water that has been processed can be recovered and disposed safely to the environment.

\section{References}

1. S. Hasiany, E. Noor, and M. Yani, Journal of Natural Resources and Environment Management, 5(1), pp.2532, (2015).

2. F. Ahmadun, A. Pendashteh, and L. Chuah, Journal of Hazardous Materials, 170, pp.530-551, (2009).
3. P. Ekins, R. Vanner, J. Firebrace, J. Clean. Prod., 15, 1302-1315, (2007).

4. Z. Khatib, P. Verbeek, Water to value-produced water management for sustainable field development of mature and green fields, in: SPE International Conference on Health, Safety and Environment in Oil and Gas Exploration and Production, Kuala Lumpur, Malaysia, 20-22 March, (2002).

5. Ministry of Environment, Regulation of the Minister of Environment Number 19 Year of 2010 regarding the quality standard of waste water for businesses and/or activities of oil and gas and geothermal, (2010).

6. J.M. Neff, Bioaccumulation in Marine Organisms: Effect of Contaminants from Oil Well Produced Water, Elsevier, The Netherlands, (2002).

7. USEPA, http://www.epa.gov

8. G.T. Tellez, N. Nirmalakhandan, J.L. Gardea-Torresdey, Advances in Environmental Research, 6, 455-470, (2002).

9. B.R. Hansen, S.H. Davies, Chemical Engineering Research \& Design, 72, 176-188, (1994).

10. J.P. Fillo, S.M. Koraido, J.M. Evans, Environmental Science Research, 46, 151-162, (1992).

11. D.T. Bostick, H. Luo, H. Hindmarsh, Characterization of Soluble in Produced Water, Oak Ridge National Laboratory, (2002). https://digital.library.unt.edu/ark:/67531/metadc 740840 /m2/1/high_res_d/814231.pdf, Online:03-07-2017

12. About produced water (Produced water 101) Available: http://aqwatec.mines.edu/produced water/intro/pw/ Online:03-07-2017

13. A white paper describing produced water from production of crude oil, natural gas, and coal bed methane. Available:

www.ipd.anl.gov/anlpubs/2004/02/49109.pdf Online:04-07-2017.

14. Z. Chen, L. Zhao, K. Lee, and C. Hannath, Water Quality Research Journal Canada, 42, 303-310, (2007a).

15. J. F. Payne, C. Andrews, L. Fancey, B. French, and Lee, K, Risks to fish associated with barium in drilling fluids and produced water: A chronic toxicity study with Cunner (Tautogolabrus adspersus). In K. Lee, \& J. Neff (Eds.), (pp. 401-417). New York: Produced Water, Springer, (2011).

16. I. Schifter, et al.,. Environ Monit Assess, 187, p.723, (2015)

17. P.J.C. Tibbetts, I.T. Buchanan, L.J. Gawel, R. Large, Environmental Science Research, 46, pp. 97-113, (1992).

18. R.P.M.W. Jacobs, R.O.H. Grant, J. Kwant, J.M. Marquenie, E. Mentzer, Environmental Science Research, 46, pp. 13-22, (1992).

19. T.I.R. Utvik, Composition, Characteristics of produced water in the North Sea, in: Produced Water Workshop, Aberdeen, Scotland, 26-27 March, (2003)

20. B. M. Johnson, L. E. Kanagy, J. H. Rodgers Jr., J.W. Castle, Water Air Soil Pollut, 191, pp. 33-54, (2008).

21. J.P. Fillo, J.M. Evans, American Gas Association Operation Section Proceedings, pp.448-459, (1990). 
22. United States Environmental Protection Agency (USEPA). EPA Office of Compliance Sector Notebook Project: Profile of the Oil and Gas Extraction Industry. EPA/310-R-99-006, (2000).

23. M.C. Shepherd, F.L. Shore, S.K. Mertens, J.S. Gibson, Environmental Science Research, 46, pp. 163-174, (1992).

24. Gazali, A.K. et al., Journal of Engineering (IOSRJEN), 7(6), pp.22-29, (2017).

25. T. Bakke, J. Klungsøyr, and S. Sanni, Marine Environmental Research, 92, pp.154-169, (2013).

26. J. Neff, K. Lee, E.M. DeBlois, Produced water: overview of composition, fates, and effects. In: Lee, K., Neff, J. (Eds.), Produced Water. Springer, New York (Chapter 1), (2011)., Available: https://id.scribd.com/document/267721195/ProducedWater-Overview-of-Composition-Fates-and-Effects Online : 05-07-2017

27. P. Odeigah, O. Nurudeen, and O. O. Amund, Hereditas 126 (2), 161-167, (1997)

28. J.M. Neff, T.C. Sauer, N. Maciolek, Environmental Science Research, 46, pp.371-386, (1992).

29. O. Obire, and F. Amusan, Journal of Applied Sciences and Environmental Management, 7 (1), 61-66, (2003).

30. DJ.K. Otton, Environmental Aspects of Producedwater Salt Releases in Onshore and Coastal Petroleum-producing Areas of the Conterminous, (2006).

https://pubs.er.usgs.gov/publication/ofr20061154, Online : 05-07-2017

31. S. Isehunwa, and S. Onovae, Journal of Engineering \& Applied Sciences, 6 (8), 66-71, (2011).

32. T.I.R. Utvik, Chemosphere, 39, 2593-2606, (1999).

33. Oil and gas produced water management and beneficial use in the western united states,

https://www.usbr.gov/research/dwpr/reportpdfs/report15 7.pdf Online : 05-07-2017

34. M.T. Stephenson, Environmental Science Research, 46, pp. 1-11, (1992).

35. D.A. Pillard, J.E. Tietge, and J.M. Evans. 1996 b. Estimating the acute toxicity of produced waters to marine organisms using predictive toxicity models. Pages 49-60 In: M. Reed and S. Johnsen (Eds.). 1996. Produced Water 2. Environmental Issues and Mitigation Technologies. Plenum Press, New York.

36. N. Elias-Samlalsingh, J. B. R. Agard, Environ. Toxicol. Chem. 23, 1194-1203, (2003).

37. S. Boitsov, S.A. Mjøs, and S. Meier. Mar. Environ. Res. 64, 651-665, (2007).

38. S.B. Henderson, S.J.W. Grigson, P. Johnson, B.D. Roddie, Mar. Pollut. Bull. 38, 1141-1151, (1999).

39. S.J.W. Grigson, A. Wilkinson, P. Johnson, C.F. Moffat, A.D. McIntosh, Rapid Commun. Mass Spectrom. 14, 2210-2219, (2000).

40. J.V. Veil, Research to Improve Water-use Efficiency and Conservation: Technologies and Practice,

(2007).

https://www.gpo.gov/fdsys/pkg/CHRG110hhrg38533/pdf/CHRG-110hhrg38533.pdf
41. J.D. Arthur, B.G. Langhus, C. Patel, Technical Summary of Oil and Gas Produced Water Treatment Technologies, (2005).

llc.com/publicdownloads/ALLConsultingWaterTreatmentOptionsReport.pdf

42. D.B. Boysen, J.E. Boysen, J.A. Boysen, Creative Strategies for Produced Water Disposal in the Rocky Mountain Region, (2002). http://ocdimage.emnrd.state.nm.us/Imaging/FileStore/Sa ntaFeAdmin/CF/61750/14015 638_CF.pdf,

43. M. Stewart, K. Arnold, Emulsion and Oil Treating Equipment, Elsivier Inc., Oxford, (2009).

44. J.A. Veil, M.G. Puder, D. Elcock and R. Jr. J.Redweik, A White Paper Describing Produced Water from Production of Crude Oil, Natural Gas, and Coal Bed Methane, US DOE (January 2004) W-31-109Eng-38

45. S. Deng, R. Bai, J.P. Chen, Z. Jiang, G. Yu, F. Zhou, Z. Chen, Sep. Purif. Technol. 29, 207-216, (2002).

46. W.M.G.T. Van den Broek, M.J. Van der Zande, Comparison of plate separator, centrifuge and hydrocyclone, in: SPE International Oil and Gas Conference and Exhibition, Beijing, China, 2-6 November, (1998)

47. T. Hayes, and D. Arthur, Overview of Emerging Produced Water Treatment Technologies. $11^{\text {th }}$ Annual International Petroleum Conference, Albuquerque, New Mexico, (2004).

48. M. N. Cakmakce, Kayaalp, et al. Desalination, 222(13), 176-186, (2008).

49. Broussard P. "Skip" Jr, Floatation Pump Proves Successful for The Treatment of Produced Water, paper presented at the $10^{\text {th }}$ IPEC, (2003).

50. ALL Consulting. Handbook on Coal Bed Methane Produced Water: Management and Beneficial Use Alternatives. Prepared by ALL, Consulting for the Ground Water Protection Research Foundation, U.S. Department of Energy, and U.S. Bureau of Land Management, (2003). http://www.al111c.com/CBM/BU/index.htm.

51. NETL. "Produced Water Management Technology Descriptions Fact Sheet.", http://www.netl.doe.gov/technologies/pwmis/techdesc/

52. J.J. Seureau, Y. Aurelle, M.E. Hoyack, A three-phase separator for the removal of oil and solids from produced water, in: SPE Annual Technical Conference and Exhibition, New Orleans, Louisiana, USA, 25-28 September, (1994)

53. Sinker, A. Produced Water Treatment Using Hydrocyclones: Theory and Practical Applications. $14^{\text {th }}$ Annual International Petroleum Environmental Conference, Houston, Texas, (2007).

54. M.S. Carvalho, M.D. Clarisse, E.F. Lucas, C.C.R. Barbosa, Evaluation of the polymeric materials (DVB copolymers) for produced water treatment, in: SPE International Petroleum Exhibition and Conference, Abu Dhabi, UAE, 13-16 October, (2002)

55. J.S.Janks, F. Cadena, Environmental Science Research, 46, pp. 473-488, (1992).

56. D.H. Doyle, F. Daniel, A.B. Brown, Field test of 
produced water treatment with polymer modified bentonite, in: SPE Rocky Mountain Regional meeting held in Casper, Wyoming, USA, 18-21 May, (1997).

57. Y. He, Z.W.Jiang, Treating oilfield wastewater: technology review, Filtr. Sep. June (2008) 14-16

58. Safitri, H.I. et al., Journal of chemical and industrial technology, 2(4), pp.205-211, (2013).

59. S. Munirasu, M. Abu, and F. Banat, Process Safety and Environmental Protection, 100, pp.183-202, (2016).

60. M. Abbasi, M. Mirfendereski, M. Nikbakht, M. Golshenas, T. Mohammadi, Desalination, 259, 169-178, (2010).
61. Zhu, X., Tu, W., Wee, K.-H., Bai, R., J. Membr. Sci. 466, 36-44, (2014).

62. Baker, R.W. (Ed.), Membrane Technolgoy and Applicatoins., second ed. John Wiley \& Sons, West Sussex, England, (2004).

63. D.D.C. Freire, M.C. Cammarota, G.L. Sant'Anna, Environ. Technol. 22, 1125-1135, (2001).

64. S. Hidayat, and E. Kardena, Removal Organic Compounds with Batch Reactor using Indogenous Bacteria and Additional Nutrition, (2007). Available at: http://www.academia.edu/31854780/25310008Syarif-Hidayat.pdf 